\title{
Union Stability and Stepfamily Fertility in Austria, Finland, France \& West Germany
}

\author{
URSULA HENZ $^{1, *}$ and ELIZABETH THOMSON ${ }^{2}$ \\ ${ }^{1}$ Department of Sociology, London School of Economics, Houghton Street, London, WC2A \\ $2 A E, U K ;{ }^{2}$ Department of Sociology and Center for Demography and Ecology, University of \\ Wisconsin-Madison, 1180 Observatory Drive, Madison, WI 53706, USA \\ (*Author for correspondence: E-mail: U.Henz@lse.ac.uk)
}

Received 16 March 2004; accepted in final form 6 October 2004

Henz, U. and Thomson, E., 2005. Union stability and stepfamily fertility in Austria, Finland, France \& West Germany, European Journal of Population, 21: 3-29.

\begin{abstract}
In this paper, we test the hypothesis that unique effects of stepfamily composition on union fertility are confounded with differences between stepfamilies and couples without stepchildren in the risk of union disruption. We use birth and union histories from Fertility and Family Surveys in Austria, Finland, France and West Germany. The risks of a union birth and separation are modeled simultaneously, allowing for the potential effects of unobserved predispositions to have a child or to separate on the other event. We test hypotheses drawn from the value of first and second shared births to couples: Net of the couple's combined parity, the birth risk will be greater if the child is (a) the first in a union, (b) the first biological child for one of the partners, or (c) the second child in a union.
\end{abstract}

Key words: fertility, stepfamily, value of children

Henz, U. et Thomson, E., 2005. Stabilité des unions et fécondité des familles recomposées en Autriche, Finlande, France et Allemagne de l'ouest, Revue Européenne de Démographie, 21: $3-29$.

Résumé. Dans cet article, nous testons l'hypothèse selon laquelle les effets de la composition de la famille recomposée sur la fécondité de l'union sont brouillés par les risques différents de rupture d'union entre familles recomposées et couples sans enfants. Nous utilisons les histoires génésiques et maritales recueillies dans les enquêtes fécondité et famille en Autriche, Finlande, France et Allemagne de l'ouest. Les probabilités de naissance dans l'union et de séparation sont modélisées simultanément, pour prendre en compte les effets éventuels sur l'autre événement de prédispositions non observées à avoir un enfant ou à se séparer. Nous testons des hypothèses basées sur la valeur d'un premier ou d'un deuxième enfant en commun pour les couples. Si l'on contrôle sur le nombre d'enfants antérieurement nés, la probabilité de naissance sera plus grande si l'enfant est le premier dans l'union, s'il est le premier enfant biologique de l'un des deux parents ou s'il est le deuxième dans l'union.

Mots clés: familles recomposées, fécondité, valeur des enfants 


\section{Introduction}

Several recent studies of stepfamily fertility have demonstrated unequivocally that step- and shared children have unique effects on a couple's subsequent childbearing (Thomson, 1997; Vikat et al., 1999; Buber and Prskawetz, 2000; Olah, 2001; Stewart, 2002; Thomson et al., 2002). Although specifications of parity effects differ across studies, they show that step children have a weaker negative effect on childbearing than shared children and that, net of stepchildren's contribution to the couple's combined parity, stepfamily partners have an increased risk of a first and often a second shared birth. Thomson et al. (2002) argue that these patterns reflect unique values of first and second shared births.

A critical component of stepfamily fertility that has received less attention is the potential difference between stepfamilies and couples without stepchildren in the risk of separation. Stepfamilies are most often formed as second or higher-order unions for at least one of the partners and therefore share the higher risk of separation for second than first unions (e.g., Martin and Bumpass, 1989; Schoen et al., 1985). Furthermore, the presence of stepchildren reduces the quality and stability of marriages (Booth and Edwards, 1992). Although some couples might try to strengthen their bond by having a child, it is more likely that couples would be reluctant to have a child when they experience difficulties in their marriage and contemplate the possibility of separation (Lillard and Waite, 1993). Women may be particularly reluctant to have children in an unstable marriage because they are likely to be the parent with primary responsibility for children if the marriage does not endure. To the extent that stepfamilies are less stable than couples without stepchildren, they should have a lower likelihood of having a child together. Thus, differences between stepfamilies and couples without stepchildren in the risk of separation may suppress part of the effect of the couple's combined parity or stepfamily configuration on their shared childbearing.

In this paper, we modify the model of Thomson et al. (2002) by removing the possibly confounding effects of union stability from the estimated effects of child configuration. This is done by simultaneously estimating models for the risk of childbearing and the risk of separation, and by allowing the unobserved heterogeneity components of the two models to be correlated. We also investigate the extent to which cross-national differences in social welfare provision condition effects of parity combinations and union stability on childbearing by reducing the direct costs to parents of rearing children.

\section{The Value of Children and Stepfamily Fertility}

Decisions by stepfamily couples to have children together arise from the unique values of first and second shared births (Bulatao, 1981; Fawcett, 
1983). A first shared child is viewed as a symbol of the couple's relationship, as for couples without stepchildren. In many stepfamilies, the first shared child is also the first born to one of the parents, providing unique values not associated with step-parenthood, such as kin ties and the continuation of a 'family line'. A second shared child may be valued for her/his biological relationship to the first, even though the child has one or more half-siblings. The values of union commitment, parental status/role, and sibling relationships may overcome higher costs that couples face when they already have children with previous partners (Griffith et al., 1985; Ganong and Coleman, 1988).

Until recently, most research on stepfamily fertility has not attended carefully to the fact that couples in stepfamilies make higher parity progressions with each shared child than do couples without stepchildren. This means that stepfamilies incur higher childrearing costs for their first shared child than couples without a stepchild. In this paper we capture parity progression in stepfamilies by controlling for the combined number of children of the two partners, which we call 'total parity'. A stepfamily couple must weigh the value of a first or a second shared child against the costs of rearing at least two or three children, respectively, rather than just one or two. If a first shared child has no added value for a stepfamily couple in terms of biological parenthood or a symbol of the couple's commitment to each other, the first birth rate of stepfamily couples should be about the same as the corresponding total parity progression rate for couples without stepchildren. Similar considerations apply for the decision to have a second shared child. Thomson et al. (2002) developed a step-parity specification that directly tests the resulting hypotheses about the union commitment, parental status and sibling values of first and second shared births. It controls for a couple's total parity and includes additional indicators for different stepfamily combinations, identifying whether the next child would be the couple's first shared child, whether it will be the first biological child of the man or the woman, or whether it will be the first shared sibling of a shared child. These indicators provide straightforward tests for differences in birth rates between couples with the same total parity but different child configurations. Thomson and her colleagues found that, net of combined parity, couples without a shared child or with only one shared child have higher birth risks than couples with two or more shared children. These results are consistent with the commitment and sibling value of first and second shared children. They did not find support for the parental status/role value of a first child when one partner had no children. In fact, couples in which one partner was not a parent were less likely to have a child together than those in which both had children with other partners. The authors suggest that the former type of union is differentially selective of partners who would not have had children in any case, whether or not they formed a partnership with a parent. The result appeared 
especially strong in West Germany where the conflict between work and family is greater than in the other countries so that individuals select themselves into life courses in which work or family (not both) is given the highest priority.

What this analysis did not consider is the possibility that stepfamilies of particular configurations may have different risks of separation, and that all stepfamilies may differ in that respect from couples without stepchildren. Lillard and Waite (1993) reported that unobserved divorce risks accounted for negative effects of stepchildren on a couple's birth risk, net of the couple's number of shared children. Using the Thomson et al. parity specification, we might find that larger combined family sizes are associated with reduced risk of separation, masking some of the negative effect of combined parity (higher for stepfamilies) on the birth risk. Similarly, if childless partners are disproportionately selected from persons with poorer relationship skills and/or lesser commitment to family life, the lower stability of their unions may account for their lower birth risk. Furthermore, the reduced risk of childbearing among couples in which only one partner has children may be attributable to relationship problems arising from the difficulty of stepparenting without prior parenting experience. By controlling for union stability, we may find that the higher risk of childbearing expected to arise from the value of first-time parenthood does in fact appear. Similarly, couples without shared children - even if both are parents - may also have a higher separation risk than couples who have demonstrated their commitment by having a child together. If we control for the potential negative effect of propensity to separate, the positive effect on fertility of having no shared children may be even stronger.

Thomson et al. also considered the possibility that costs of childrearing would be lower in countries with more generous social welfare systems, thereby enabling stepfamilies to afford the larger family size produced by first or second shared births. Although they did not find the expected pattern of higher stepfamily birth risks in countries with greater supports for childrearing, such differences might show up when union stability is controlled. For example, higher rates of separation in Finland, France and Austria could mask the expected higher risk of stepfamily childbearing in these countries compared to West Germany.

\section{Data and Methods}

Our selection of Fertility and Family Surveys for analysis is in part data driven. Austria, Finland, France and West Germany were the only "western" European countries in which (1) stepfamilies are sufficiently common to produce a reasonable number of cases for analysis; and (2) data were collected on the number of children of previous partners. The 
latter criterion enables us to provide a full specification of partners' separate and shared parities. The countries are also, however, broadly representative of variations in systems of social insurance that support parenthood and/or gender equality, cultural beliefs about gender, and institutionalization of cohabitation as an alternative to marriage (Bosveld, 1996; Orloff, 1996).

Finland, for example, offers a high level of support for childrearing and gender equality (Rönsen and Sundström, 1997). Divorce and cohabitation has increased, but non-union births are rare (Prinz, 1995; Nikander, 1998). France also provides generous transfers to parents, but primarily for reasons of pronatalism rather than gender equality. Child care is relatively well subsidized for toddlers but not infants (Toulemon and de Guibert-Lantoine, 1998). Austria's support for childrearing is similarly generous and reasonably good child care is provided for two years prior to children's school entry (Findl, 1991). Austria, France and Finland have similar cohabitation and union dissolution rates (Andersson and Philipov 2002; Nikander, 1998; Prinz, 1998; Toulemon and de Guibert-Lantoine, 1998). Austria but not France has a high rate of non-union births (Kiernan 1999; Prinz, 1998. Toulemon and de Guibert-Lantoine, 1998). Finally, although West German payments to parents are also generous, child care is limited in comparison to other European countries and the organization of the school day makes it very difficult to combine employment and parenthood (Höhn, 1991). As a result, female employment is relatively low, especially among mothers of young children. Non-marital births are quite low (Andersson and Philipov 2002; Kiernan 1999; Prinz, 1995). Overall, these four countries range from more liberal to more conservative in their social welfare regimes, with West Germany's lower separation rate standing out from those of the other three countries.

FFS surveys differed somewhat across countries. In Finland, samples were drawn from population registers; other countries relied on stratified household samples. Larger numbers of females than males were generally targeted. Response rates were all above $72 \%$. The age ranges vary somewhat, but are centered on the reproductive years. Each survey includes complete birth and union histories (by month and year) from the respondent, allowing us to assign each child to a particular union or to a period of singlehood. As noted above, respondents also provide information on the number of children each partner had at the time the union was formed. ${ }^{1}$ Our analytic samples exclude foreign-born respondents because we are interested in the welfare regimes underlying union events and births, and foreign-born respondents may have experienced some part of their union and birth history under a different welfare regime. We also exclude couples without children; because all stepfamilies have at least one child, only comparisons with couples making progressions to second or 
higher-order parities provide tests of the added value of shared births in stepfamilies.

We use the couple's combined parity at union formation (one, two, three or more children) as our control for the cost of having another child. Bulatao (1981) has shown that perceived economic and other costs of children are positively associated with the number of children, making no difference between stepchildren and biological children. When resident and non-resident stepchildren were studied separately, non-resident children turned out to have a slightly lower negative impact on childbearing in Austria and Finland (Vikat et al., 2004). However, this difference is too small to seriously challenge our claim that all children matter in the prospective decision.

We add five dummy variables representing prospective births to stepfamilies that would provide particular sorts of value:

Couple has no shared child;

Only the woman has children;

Only the man has children;

Couple has one shared child and one or more separate children;

Couple has two or more shared children and one or more separate children.

Couples without stepchildren receive a score of zero on all five step-parity variables, and each stepfamily receives a one on at least one of the variables. Note that the second and third types of stepfamilies (only one partner has children) are subsets of the first (no shared children). The effect of these two dummy variables is contrasted to (net of) the effect of having no shared child.

The primary event of interest is the conception of a live birth, calculated to occur nine months prior to the birth itself. A birth interval may begin at union formation (for the first birth to stepfamily couples) or after a birth within a union (all other intervals). Observations are censored when the couple separates, the woman reaches age 45 or the man reaches age 50 , or at nine months before the interview, whichever occurs first. The last condition means that we ignore information on pregnancies reported at the interview that may or may not result in live births. Respondents are excluded from analysis after a multiple birth, because parity does not represent the same experience of childbearing for these births.

Births outside of unions are not included as events in the hazard models, but are included in counts of the respondent's or partner's children. That is, we compare stepfamily couples to couples without stepchildren, not to single women. Children born no more than 12 months prior to union formation (coresidence) are assumed to be the children of the couple, unless the respondent reported a prior union at the time of conception. In such cases, we treat the couple as having one shared child at union formation, and specify the next birth interval to begin at union formation. Couples in which the woman was pregnant at union formation (i.e., had a child less than nine 
months after union formation) are treated in a similar fashion, with the subsequent birth interval beginning when the child is born.

The separation models are likewise restricted to couples with children because childless couples and couples with children experience different threats to union stability. Observations for the risk of separation also begin in the month of union formation for stepfamilies or for couples who had a shared child before the start of the union, and after the first birth in a union for other families. They are censored when the woman reaches age 45 or the man reaches age 50 or at 9 months before the interview, whichever occurs first. That is, we are interested in the dissolution of unions with children during the childbearing years as a factor in the birth risk. As for the birth risk, observations are excluded after the respondent has a multiple birth.

The baseline clocks for each hazard are specified as linear splines with nodes at one, two, five and ten years for the fertility model and at one, three, five and ten years in the separation model. ${ }^{2}$ Measures of combined and stepparity variables are included in the equation for each risk - as fixed variables for birth risks and as time-varying variables for separation risks. We do not include union status (married, cohabiting) in either model, believing it is endogenous to both risks. In both equations, we include partners' ages as time-varying linear splines with nodes at 25, 30, 35 years for women's age, and an added node at 40 for men's age except in West Germany where the sample was limited to respondents under 40. In the French data set a rather large proportion of respondents did not report partner's age. In the French models observations with missing partner's age are not excluded from the analyzed sample; instead a node is added to the spline measuring the effects of partner's age. ${ }^{3}$ Both risks include controls for fixed calendar time at the start of the birth interval or at the start of the union in form of linear splines with nodes at 1970 and 1980, except in West Germany and France where only a single node at 1980 is chosen. All models are estimated separately for male and female respondents in each country, using the $a M L$ software (Lillard, 1993; Lillard and Panis, 2000).

We first estimate parallel models of each hazard rate, without unobserved heterogeneity coefficients. We then add estimates of unobserved heterogeneity in each equation, and in the final equation we allow the heterogeneity components to be correlated. The reason why we incorporate unobserved heterogeneity terms into our models is that we suspect that couples with and without a stepchild may differ in unobserved traits that affect their fertility decisions. If this is true the estimated effects of child configuration could partly represent other differences between the couples, e.g. differences in family values, or differences in the pressures on the partnership. The framework developed by Lillard (1993) provides a unique opportunity to not only allow for unobserved heterogeneity but to provide some substantial interpretation of these effects. While we do not know in general what kind of 
unobserved characteristics influence the birth rates and the separation rates, the potential correlation of the error terms provides some further information about the nature of the unobserved characteristics. If we find that the two error terms are negatively correlated, we can conclude that the same unobserved characteristics that increase the dissolution rates tend to lower the birth rates, and vice versa; then the two processes are mutually endogenous. In addition, some estimated parameters might change when we include unobserved heterogeneity terms. If any effects of step-parity variables in the birth models are altered when we control for the potential mutual endogeneity of the two family processes, we conclude that the previously estimated effects incorporated differences attributable not only to step-parity but also to relationship stability. The model with correlated heterogeneity estimates differences by step-parity that would be observed if stepfamilies and partnerships without stepchildren experienced the same union stability. Therefore, our key question is whether effects of step-parity variables are altered when we control for the potential mutual endogeneity of these two family processes.

Following Lillard (1993), the unobserved heterogeneity is captured by two error terms that are jointly normally distributed. Their estimated standard deviations sig1 (in the fertility model) and sig2 (in the separation model) are given in appendix B as well as their estimated correlation coefficient rho. The model assumes that the residuals are constant for each respondent and do not change over time. Thereby the residuals can capture unobserved stable characteristics of the respondent, or they capture some kind of "lifetimeaverage" characteristics. Appendix A gives a formal exposition of the model.

\section{Results}

Table 1 presents the number of valid cases and age ranges for men and women in each country, and selected descriptive statistics. Although the ages at which we are able to observe unions and births vary across countries, the proportion of intervals resulting in conception leading to a live birth was very similar, approaching 50\%. Only West German respondents reported a substantially lower proportion of births. Most couples do not, of course, have stepchildren, but a substantial proportion of couples in each country have separate children of the woman, the man, or both. Of all intervals observed, between 10 and $20 \%$ occurred in a stepfamily; this includes intervals after a stepfamily couple's first or second or higher-order shared birth. Only about $10 \%$ of the intervals began at the formation of a stepfamily. In the divorce models, the proportion of unions with children that end in separation varies considerably between the countries, ranging from $13 \%$ for West German men to over $30 \%$ for French women. In all countries a considerable share of 


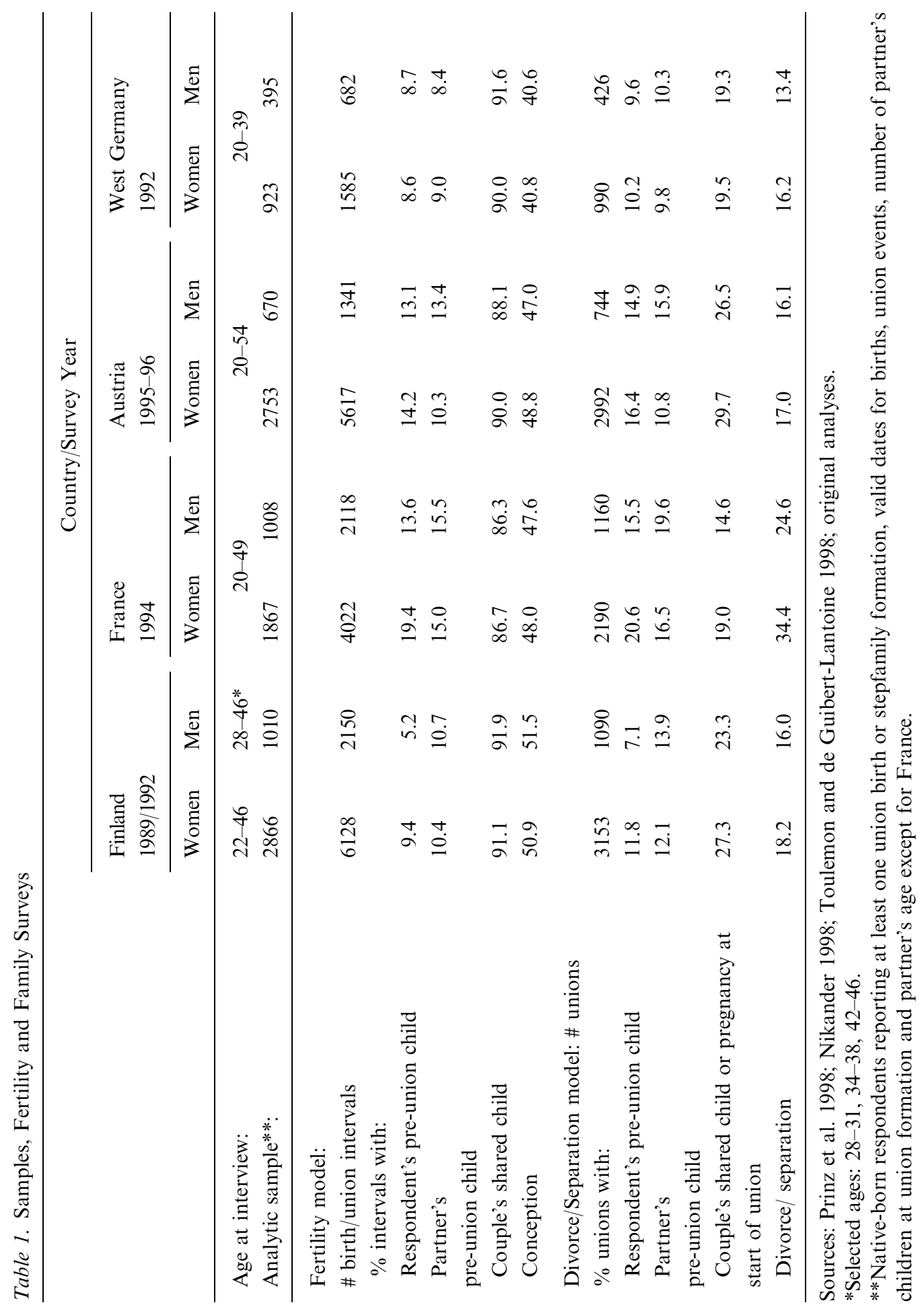


unions include stepchildren, namely between 20 and 30\%. These numbers are adequate for the models we estimate and in most cases provide sufficient statistical power to estimate differences in the birth and separation risks for different types of stepfamilies.

Figures 1 and 2 show estimated conception and separation rates if only the baseline duration splines and a constant are included in the models. The conception rates show a rather homogenous pattern with a peak after one or two years of duration and a continuous decline afterwards. The separation rates follow more varied patterns, with Austrian and Finnish unions having increased separation risks in the first five years and lower risks thereafter, as

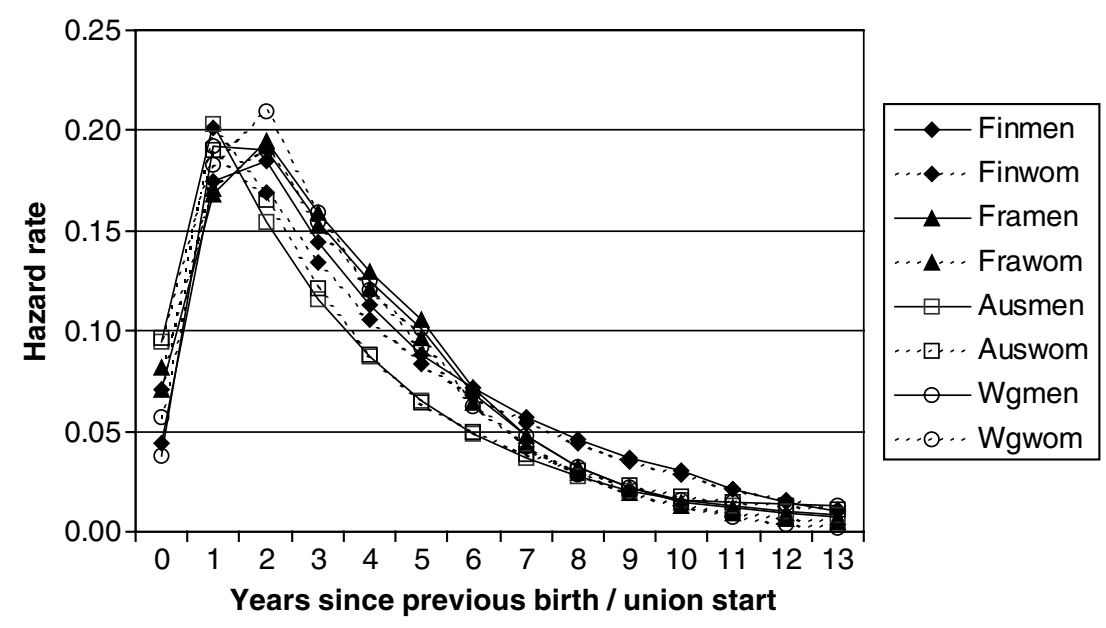

Figure 1. Conception rates.

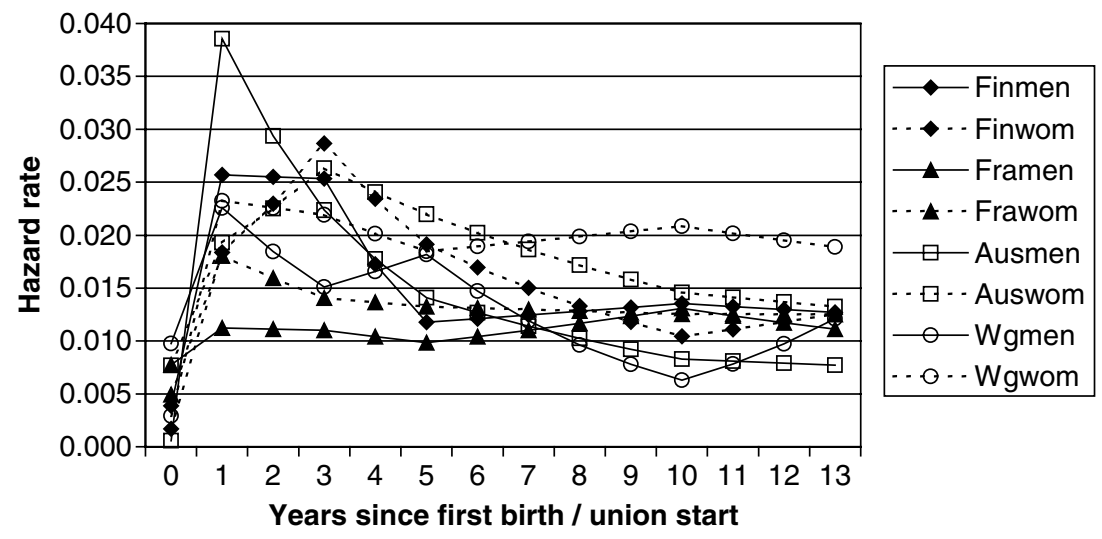

Figure 2. Union dissolution/separation rates. 
UNION STABILITY AND STEPFAMILY FERTILITY

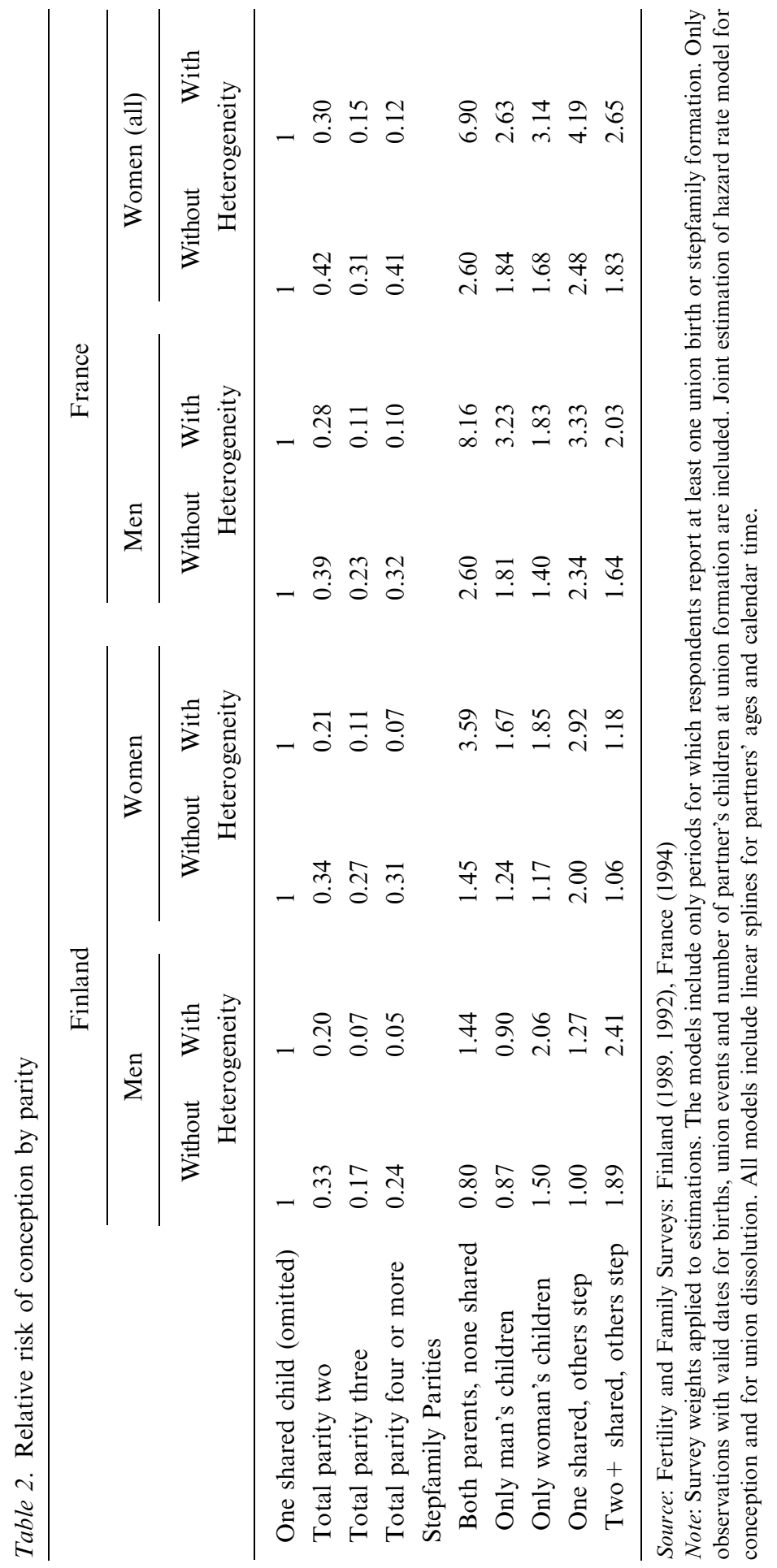




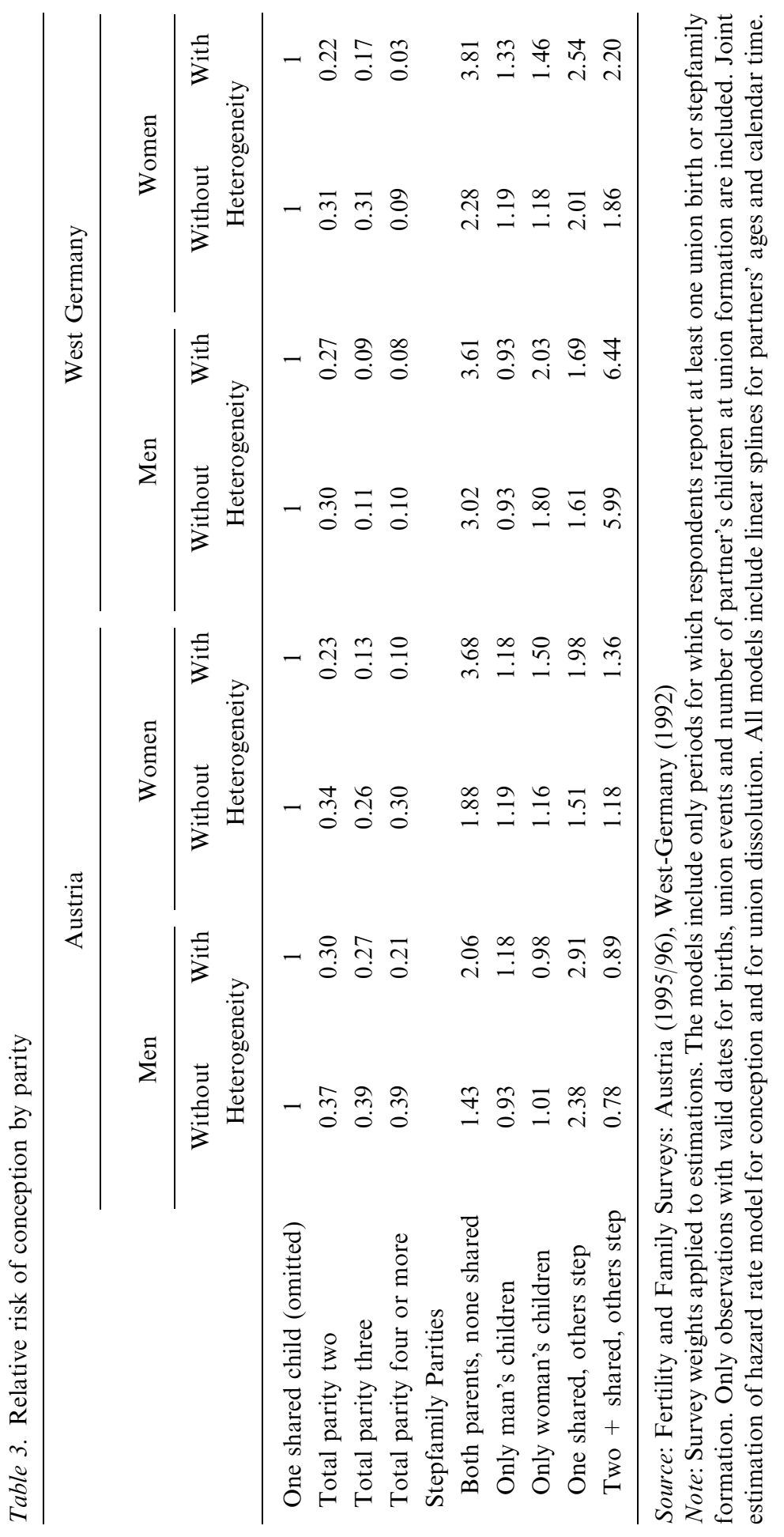




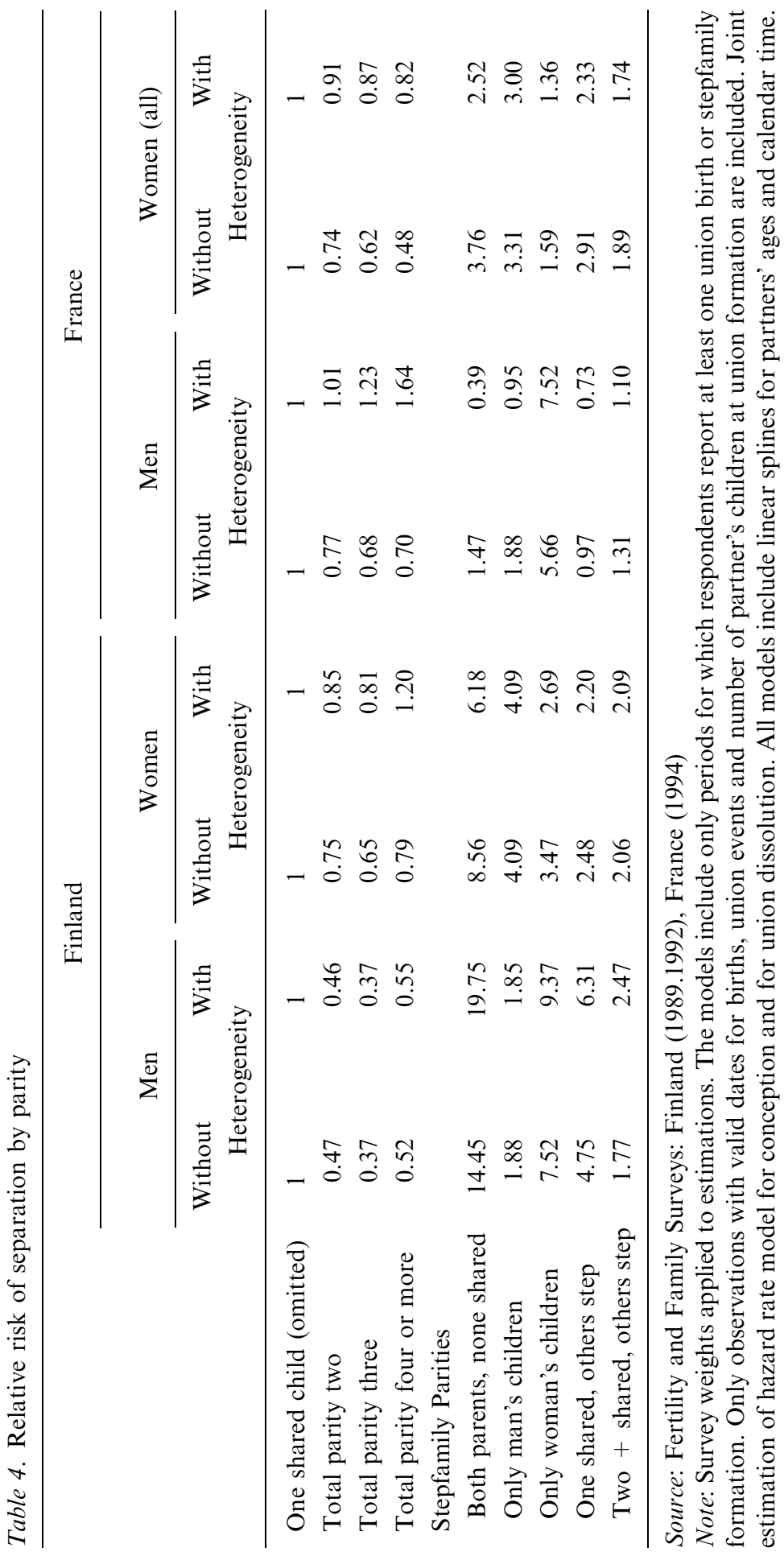




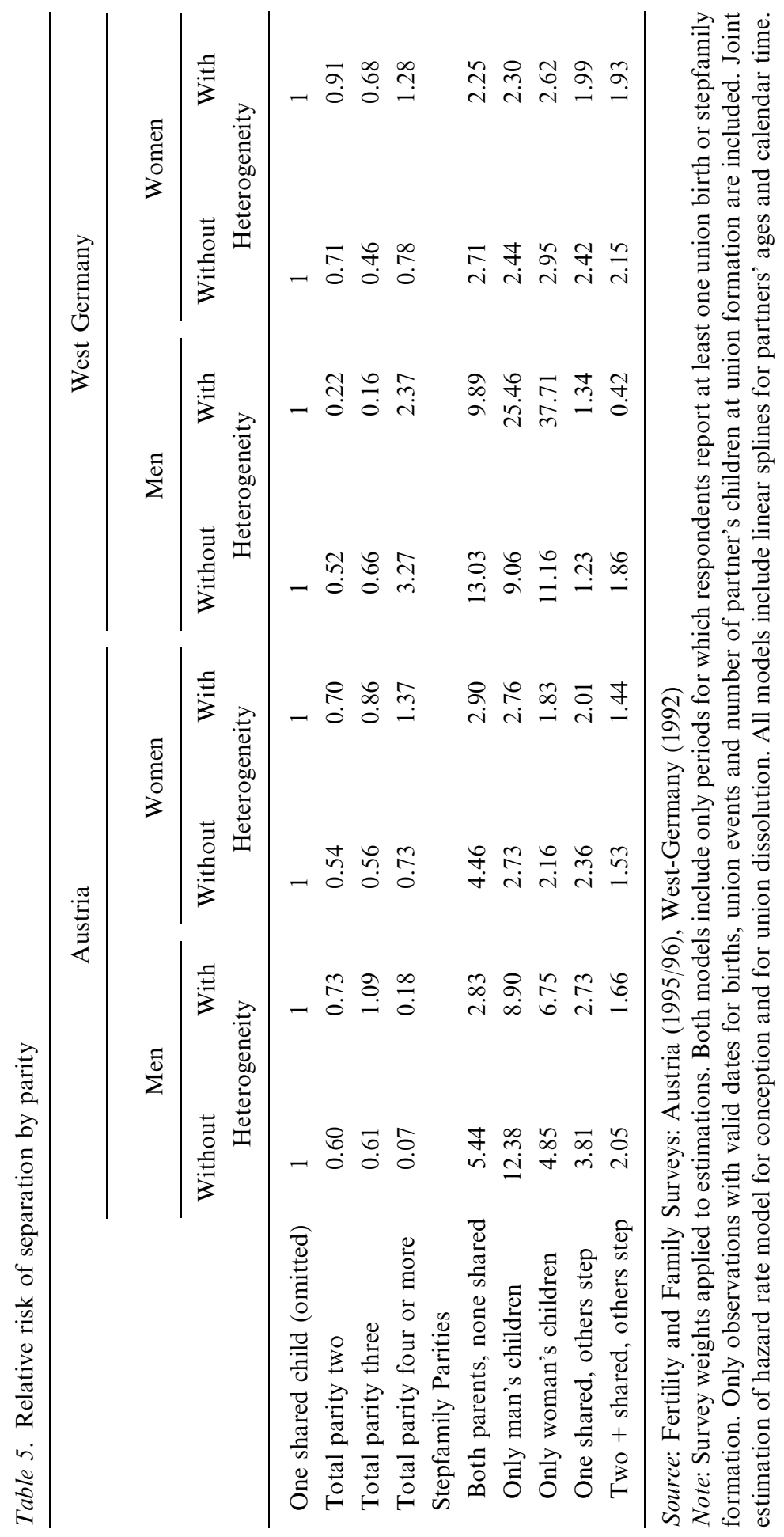


do West German men, while separation risks of West German women and of French couples do not vary much after the first year of duration.

Tables 2 and 3 present relative conception risks (exponentiated hazard coefficients) by combined parity and step-family configuration for, respectively, Finland, France, Austria and West Germany. ${ }^{4}$ Model 1 (without heterogeneity) includes the risk of separation as a parallel process. Model 2 (with heterogeneity) specifies that each risk has an unobserved heterogeneity component and that the two components are correlated. The original model parameters and parameters for the separation risk are included in appendix B. The full model estimations are available on the journal's website. The estimation algorithm did not converge for the model for French women with unobserved heterogeneity and the estimated correlation of the heterogeneity terms $(\rho)$ approached one. Appendix B includes a second model estimation for French women where some birth intervals are excluded for women with a large number of stepchildren or shared children; only intervals where women themselves or their partners had each up to two children from earlier relationships are included, and only up to the third shared birth in a union. ${ }^{5}$ For this slightly smaller sample the estimation algorithm converged. The estimated model parameters show a similar pattern as the model based on the full sample. The correlation of the error terms is still high, although insignificant in both models.

While all other model estimations converged it is necessary to point out that the results for West German men are based on a rather small number of observations. The large relative risks in the separation model are likely to be unstable, due to the small number of 57 separations in the sample.

In the models without heterogeneity terms, estimated effects are essentially the same as those reported by Thomson and her colleagues. Births are less likely at higher combined parities. Net of combined parity, couples without shared children have higher birth risks than do those with shared children, unless one of the partners has no previous children. In that case, the birth risks are lower than those for 'blended' families (her and his children), and equal to or only somewhat higher than those for couples with the same number of shared children. Birth risks are in most models elevated for couples with only one shared child (and one or more stepchildren). In West Germany, stepfamily couples with two or more shared children are also more likely to have another child than they would if all of their children were shared; a similar pattern in France is not as pronounced.

Tables 4 and 5 show relative separation risks associated with different parities and child configurations. Separation risks of stepfamilies are consistently higher than separation risks of families with only shared children. Even after having a first shared child, stepfamilies experience a considerably higher separation risk. The same is true for stepfamilies with a second shared child but none of the model coefficients is statistically significant. Mixed 
patterns emerge concerning the parenthood variables. For West Germans and for Austrian men the separation rates do not differ significantly between couples where both are parents or where only the man or only the woman is a parent; for Finns, Austrian women and French women the separation rates are especially high for couples where each partner has a child from an earlier partnership; and for French men the separation rate is highest if only the woman is a parent.

Turning to the models that account for unobserved heterogeneity, we see from the models in appendix $\mathrm{B}$, that both the birth risk and the separation risk are incompletely explained by observed indicators, and that the unobserved propensity to have a child together and the unobserved propensity to separate are negatively correlated. The association is not, however, statistically significant, in most cases. A negative correlation between unobserved components of separation and births is consistent with the two risks having a common cause such as the potential for intimacy, family orientation, etc.

When we control for the unobserved negative association between the risk of separation and birth, we find, as expected, that the parity effects become stronger in Tables 2 and 3. That is, part of the negative effect of combined parity on childbearing (representing childrearing costs) is offset by greater stability of partnerships with large numbers of children - stability that leads to higher fertility. In Finland, for example, couples with two children are about one-third as likely to have a child as those with one child; when the greater stability of two-child unions is taken into account (and positive effects of stability on childbearing), the relative rates drop to about one fifth. The latter rates more accurately represent effects of childrearing costs for couples with two, three, four or more children.

In a parallel fashion, the lower stability of stepfamilies works against the positive force of unique child values produced by first and second shared children. If stepfamily partnerships were as stable as those without stepchildren, we would find an even greater risk of childbearing for couples who have no shared children or only one shared child. In Finland, these effects are limited to couples who are both parents but who have no shared children. Among male respondents, relative rates are increased by more than half ( 1.44 versus 0.80 ); for women the relative risk is doubled (3.59 versus 1.45). Similar increases are found in the relative risk of a second or in some cases a third shared birth to stepfamily couples.

Contrary to our hypothesis, union stability does not mask to any significant degree a positive effect of one or the other partner having no children. Although these couples may be more likely to have a child than couples with the same combined parity but no stepchild, they do not approach the birth rates for couples in which each partner has one or more children but no shared children. We cannot conclude, therefore, that union stability 
contributes to the higher childbearing rates of partners who each have separate children.

Although we find parallel patterns across countries, considerable differences remain. Thomson and her colleagues did not find larger positive effects of having fewer than two shared children and/or smaller effects of combined parity in countries with more generous supports for childrearing, but we thought that the relatively higher separation rates in countries with more generous social welfare regimes could have masked such effects. The differences observed across countries remain, however, in the model with unobserved correlated heterogeneity components, and they are not consistent with the hypothesis - at least as strong effects of having no shared children are observed in West Germany as in countries with more generous childrearing supports.

\section{Discussion and Conclusions}

These analyses provide even stronger evidence than provided by previous research for the unique values of first and second births. As Thomson et al. (2002) demonstrated, couples who have no shared children or only one shared child have a higher birth risk than do couples who have the same number of children, all shared. And parity effects representing the value of first and second shared births are even stronger when we account for the relatively higher risk of separation among stepfamily couples. The relative risks were in several cases double those estimated without controlling for unobserved differences in union stability.

We did not, however, find that the stepfamily couples with the lowest birth risk - those in which all of the stepchildren belong to the man or to the woman - had relatively higher risks, once we controlled for unobserved differences in the risk of separation. These results suggest that the value of a first shared birth is not enhanced when it is also the first birth for one of the partners. This result is puzzling, especially because our models also include an unobserved heterogeneity component for the birth risk. If childless partners are selected from a pool with relatively low interests in parenthood, the unobserved component of the birth risk should be picking up such differences. Our analysis also demonstrates that the 'plateau' in birth risks at parities two or higher is due in part to the relatively greater stability of couples with larger family sizes. Once we control for unobserved differences in the separation risk, relative birth risks declined more steeply with increasing family size, consistent with increasing costs of rearing larger numbers of children.

By controlling for unobserved risks that are negatively correlated, we were able to identify net effects of opposing forces underlying couples' birth risks - 
the values and costs of prospective births (represented by combined parity and stepfamily configuration) and union stability. These methods have a much wider applicability, enabling demographers of the life course to refine tests of theoretical processes underlying risks of life events. Much of the research on life course processes makes use of retrospective histories where we cannot observe such theoretically important variables as the quality of family relationships, individual values and ideologies, and personal abilities. We must make inferences about effects of such variables from effects of characteristics and experiences that respondents can reasonably report retrospectively, each of which may influence the life course through two or more different theoretical mechanisms (e.g., values of children and union stability). Where we can identify competing or simultaneous risks that should be differentially influenced by a particular characteristic or experience, we may be able to use these methods to draw firmer conclusions about our theoretical claims.

\section{Acknowledgements}

This research was supported by Grant HD36275 and Center Grant HD05086 from the U.S. National Institute of Health, National Institute of Child Health and Human Development and by the respective institutions of the coauthors. We thank Isabella Buber, Amy L. Godecker, Jan M. Hoem, Vladimira Kantorova, Jui-Chung Allen Li, Alexia Prskawetz, and Laurent Toulemon for assistance with data preparation. The German Federal Institute for Population Research kindly provided the German data. Earlier versions of the paper were presented at the Annual Meeting of the American Sociological Association, August 2002, and at the European Population Conference, August 2003.

\footnotetext{
Notes

${ }^{1}$ Because information on the deaths of partners' children is available only if the child lived with the respondent and remained in the household until death, and because we want parallel data on respondent's and partner's children, we ignore child deaths in computing parity. The proportion of respondents reporting a child who died before the respondent reached the end of her/his childbearing years is exceedingly small.

${ }^{2}$ This means that the baseline function is approximated by a linear function in each of the sub-intervals defined by the nodes. Slopes may differ from one segment to the other, but each subsequent linear function must start where the previous function ended.

3 The node is above most ages in the sample, that is at age 50 for female and at age 60 for male partners. Thereby the slope for the age interval from 35 to 50 for female partners and from 40 to 60 for male partners should correctly depict changes in separation rates by partners' ages within this age range. If the slope after age $50 / 60$ is positive, the separation rate of couples with missing age of the partner is higher than that of couples where the partner is $50 / 60$ years old. If
} 
the slope is negative, the separation rate of couples with missing age of the partner is lower compared to couples with partners in the highest age range in the sample.

4 The relative risk of "Only man's children" is the exponentiated sum of the effect for having no shared child and the woman not yet being a parent. Similarly, the relative risk of "Only woman's children" is the exponentiated sum of the effects for having no shared child and the man not yet being a parent. All other relative risks are calculated as exponentiated parameters of the respective estimated model parameter.

5 The French data includes some extreme numbers of children from previous partners; respondents had up to six children and partners had up to eight children from previous relationships. Excluding extreme cases reduces the number of birth/union intervals to 3667 and the number of conceptions from 1931 to 1896.

\section{Appendix A: Model specification}

Our models follow the framework for simultaneous equations for hazard rate models developed by Lillard (1993); other applications of these models can be found for example in the studies by Lillard and Waite (1993), Lillard, Brien and Waite (1995), Upchurch, Lillard and Panis (2002) and Baizan, Aassve and Billari (2003). For each partnership of a respondent we estimate the risk of separation from a piecewise-linear log-hazard rate model. For each birth interval of a respondent in a partnership we estimate the risk of childbirth, applying also here a piecewise-linear log-hazard rate model. In our final model we assume that unobserved characteristics influence the birth and the dissolution rates, and that these error terms follow a joint normal distribution. With $\lambda_{\text {birth }}$ and $\lambda_{\text {divorce }}$ the two hazard rates in question, the model can be written as

$$
\begin{aligned}
\ln \lambda_{\text {birth }}(t \mid X) & =\gamma_{\text {birth }} T_{\text {birth }}(t)+\beta_{\text {birth }}^{\prime} X\left(t_{b 0}+t\right)+\delta_{\text {birth }} \text { and } \\
\ln \lambda_{\text {divorce }}(t \mid X) & =\gamma_{\text {divorce }} T_{\text {divorce }}(t)+\beta_{\text {divorce }}^{\prime} X\left(t_{d 0}+t\right)+\delta_{\text {divorce }} \\
\text { with }\left(\begin{array}{c}
\delta_{\text {birth }} \\
\delta_{\text {divorce }}
\end{array}\right) & \sim N\left(\left(\begin{array}{l}
0 \\
0
\end{array}\right),\left(\begin{array}{cc}
\sigma_{\text {birth }}^{2} & \rho \\
\rho & \sigma_{\text {divorce }}^{2}
\end{array}\right)\right) .
\end{aligned}
$$

In the divorce model the duration $t$ is measured since $t_{d 0}$, which is the time of partnership formation for stepfamilies and for other couples that already had a shared child at that time. For all other couples the duration is measured since the birth of the first shared child. In the birth model the duration is the time since $t_{b 0}$, which indicates the date of partnership formation for stepfamily couples without a shared child and the date of the previous birth for all other couples. As explained in the text, we exclude couples without any children at all, shared or separate. $\gamma_{\text {birth }} T_{\text {birth }}(t)$ and $\gamma_{\text {divorce }} T_{\text {divorce }}(t)$ represent the baseline hazard rates of a birth or a divorce, respectively, each of which is a piece-wise linear spline function. $T_{\text {birth }}(t)$ gives the nodes for 
the birth rate model, which are chosen as $0,1,2,5$, and 10 years of duration, while the vector $\gamma_{\text {birth }}$ contains the slope parameters. In the divorce model the nodes $T_{\text {divorce }}(t)$ are specified as $0,1,3,5$, and 10 years of duration. $X(t)$ is the vector of (possibly time-varying) covariates with estimated effects $\beta_{\text {birth }}$ and $\beta_{\text {divorce. }} X(t)$ includes the same covariates in the birth model and the divorce model. $\delta_{\text {birth }}$ and $\delta_{\text {divorce }}$ are unobserved respondent-specific error terms, drawn from a bivariate normal distribution with expectation 0 , standard errors $\sigma_{\text {birth }}$ and $\sigma_{\text {divorce }}$ and error correlation $\rho$. The tables in Appendix B show first model estimations without the error components $\delta_{\text {birth }}$ and $\delta_{\text {divorce }}$, and then the estimations from the model presented in the formulas above.

Appendix B: Selected parameter estimates; asymptotic standard errors in parentheses; weighted data. Complete model estimations are available on the journals website.

\begin{tabular}{|c|c|c|c|c|}
\hline & \multicolumn{4}{|c|}{ Finland } \\
\hline & \multicolumn{2}{|c|}{ Men } & \multicolumn{2}{|c|}{ Women } \\
\hline & Without & With & Without & With \\
\hline & \multicolumn{2}{|c|}{ Heterogeneity } & \multicolumn{2}{|c|}{ Heterogeneity } \\
\hline \multirow{2}{*}{\multicolumn{5}{|c|}{$\begin{array}{l}\text { Fertility model } \\
\text { Combined parity }\end{array}$}} \\
\hline & & & & \\
\hline Two & $\begin{array}{l}-1.11 * * * \\
(0.08)\end{array}$ & $\begin{array}{l}-1.60 * * * \\
(0.11)\end{array}$ & $\begin{array}{l}-1.07 * * * \\
(0.05)\end{array}$ & $\begin{array}{l}-1.55^{* * * *} \\
(0.06)\end{array}$ \\
\hline Three & $\begin{array}{l}-1.77 * * * \\
(0.14)\end{array}$ & $\begin{array}{l}-2.72 * * * \\
(0.20)\end{array}$ & $\begin{array}{l}-1.32 * * * \\
(0.08)\end{array}$ & $\begin{array}{l}-2.24 * * * \\
(0.10)\end{array}$ \\
\hline Four or more & $\begin{array}{l}-1.41 * * * \\
(0.21)\end{array}$ & $\begin{array}{l}-2.96^{* * * *} \\
(0.31)\end{array}$ & $\begin{array}{l}-1.16^{* * *} \\
(0.09)\end{array}$ & $\begin{array}{l}-2.60 * * * \\
(0.14)\end{array}$ \\
\hline \multicolumn{5}{|l|}{ Stepfamily type } \\
\hline No shared & $\begin{array}{l}-0.22 \\
(0.94)\end{array}$ & $\begin{array}{l}0.36 \\
(0.91)\end{array}$ & $\begin{array}{l}0.37^{*} \\
(0.20)\end{array}$ & $\begin{array}{l}1.28 * * * \\
(0.23)\end{array}$ \\
\hline Only woman's & $\begin{array}{c}0.63 \\
(0.95)\end{array}$ & $\begin{array}{l}0.36 \\
(0.92)\end{array}$ & $\begin{array}{l}-0.21 \\
(0.22)\end{array}$ & $\begin{array}{l}-0.66^{* * *} \\
(0.24)\end{array}$ \\
\hline Only man's & $\begin{array}{c}0.09 \\
(0.94)\end{array}$ & $\begin{array}{l}-0.47 \\
(0.90)\end{array}$ & $\begin{array}{l}-0.16 \\
(0.21)\end{array}$ & $\begin{array}{l}-0.76^{* * * *} \\
(0.24)\end{array}$ \\
\hline One shared & $\begin{array}{c}0.00 \\
(0.21)\end{array}$ & $\begin{array}{l}0.24 \\
(0.23)\end{array}$ & $\begin{array}{l}0.70 * * * \\
(0.09)\end{array}$ & $\begin{array}{l}1.07 * * * \\
(0.12)\end{array}$ \\
\hline Two + shared & $\begin{array}{l}0.64 * * \\
(0.32)\end{array}$ & $\begin{array}{l}0.88 * * \\
(0.43)\end{array}$ & $\begin{array}{l}0.06 \\
(0.15)\end{array}$ & $\begin{array}{l}0.17 \\
(0.17)\end{array}$ \\
\hline
\end{tabular}


Appendix B: (Continued)

\section{Divorce model}

Combined parity

Two

Three

Four or more

Stepfamily type

No shared

Only woman's

Only man's

One shared

Two + shared

\section{Heterogeneity Model}

sig1

sig2

rho

$\begin{array}{llll}-0.75^{* * *} & -0.79 * * & -0.29^{* * *} & -0.16 \\ (0.19) & (0.32) & (0.11) & (0.17) \\ -0.99^{* * *} & -0.99^{*} & -0.44^{* * *} & -0.21 \\ (0.31) & (0.56) & (0.16) & (0.26) \\ -0.65 & -0.61 & -0.23 & 0.18 \\ (0.49) & (0.90) & (0.21) & (0.37)\end{array}$

$2.15^{* * *}$

$1.82 * * *$

$(0.24)$

$(0.34)$

$-0.90^{* * *} \quad-0.83^{* *}$

$(0.28)$

$(0.35)$

$-0.74 * * * \quad-0.41$

$(0.28) \quad(0.36)$

$0.91 * * * \quad 0.79 * * *$

$(0.19) \quad(0.22)$

$0.73 * * * \quad 0.74 * * *$

$(0.25)$

(0.28)
$2.67 * * *$

$(0.52)$

$-0.65$

(0.51)

$-2.04 * * *$

(0.68)

$1.56^{* * *}$

(0.29)

0.57

(0.80)

$2.98 * * *$

(0.79)

$-0.75$

(0.73)

$-2.37 * *$

(0.98)

$1.84 * * *$

(0.39)

0.90

(0.94)

$0.88^{* * *}$

(0.08)

$1.23 * * *$

$(0.24)$

$-0.19$

$(0.25)$

$-6205.2$

$-6231.3$

ln-Likelihood

$0.91^{* * *}$

(0.04)

$0.85 * * *$

(0.17)

$-0.30^{*}$

$(0.16)$

Note: Significance: $*=10 \% ; * *=5 \% ; * * *=1 \%$

The models also control for duration, respondent's age, partner's age and calendar year both in the fertility and the divorce model.

\begin{tabular}{|c|c|c|c|c|c|}
\hline & \multicolumn{5}{|c|}{ France } \\
\hline & \multicolumn{2}{|c|}{ Men } & \multicolumn{3}{|c|}{ Women } \\
\hline & Without & With & Without & With $^{\mathrm{a}}$ & With $^{\mathrm{b}}$ \\
\hline & \multicolumn{2}{|c|}{ Heterogeneity } & \multicolumn{3}{|c|}{ Heterogeneity } \\
\hline \multirow{2}{*}{\multicolumn{6}{|c|}{$\begin{array}{l}\text { Fertility model } \\
\text { Combined parity }\end{array}$}} \\
\hline & & & & & \\
\hline Two & $\begin{array}{l}-0.94 * * * \\
(0.08)\end{array}$ & $\begin{array}{l}-1.27^{* * *} \\
(0.11)\end{array}$ & $\begin{array}{l}-0.87^{* * *} \\
(0.06)\end{array}$ & $\begin{array}{l}-1.19 * * * \\
(0.07)\end{array}$ & $\begin{array}{l}-1.26^{* * *} \\
(0.07)\end{array}$ \\
\hline
\end{tabular}


Appendix B: (Continued)

\begin{tabular}{|c|c|c|c|c|c|}
\hline & \multicolumn{5}{|c|}{ France } \\
\hline & \multicolumn{2}{|c|}{ Men } & \multicolumn{3}{|c|}{ Women } \\
\hline & $\begin{array}{r}\text { Without } \\
\text { Hete }\end{array}$ & $\begin{array}{l}\text { With } \\
\text { neity }\end{array}$ & Without & Heterogeneity & With $^{\mathrm{b}}$ \\
\hline Three & $\begin{array}{l}-1.48 * * * \\
(0.14)\end{array}$ & $\begin{array}{l}-2.18 * * * \\
(0.20)\end{array}$ & $\begin{array}{l}-1.17^{* * * *} \\
(0.09)\end{array}$ & $\begin{array}{l}-1.93^{* * * *} \\
(0.12)\end{array}$ & $\begin{array}{l}-2.24 * * * \\
(0.12)\end{array}$ \\
\hline Four or more & $\begin{array}{l}-1.13^{* * *} \\
(0.19)\end{array}$ & $\begin{array}{l}-2.34 * * * \\
(0.29)\end{array}$ & $\begin{array}{l}-0.90^{* * * *} \\
(0.11)\end{array}$ & $\begin{array}{l}-2.11^{* * *} \\
(0.17)\end{array}$ & $\begin{array}{l}-2.59 * * * \\
(0.25\end{array}$ \\
\hline \multicolumn{6}{|l|}{ Stepfamily type } \\
\hline No shared & $\begin{array}{l}0.95^{* * * *} \\
(0.37)\end{array}$ & $\begin{array}{l}2.10 * * * \\
(0.42)\end{array}$ & $\begin{array}{l}0.95 * * * \\
(0.20)\end{array}$ & $\begin{array}{l}1.93^{* * *} \\
(0.23)\end{array}$ & $\begin{array}{l}2.26 * * * \\
(0.30)\end{array}$ \\
\hline Only woman's & $\begin{array}{l}-0.62 \\
(0.39)\end{array}$ & $\begin{array}{l}-1.50 * * * \\
(0.43)\end{array}$ & $\begin{array}{l}-0.44^{* *} \\
(0.22)\end{array}$ & $\begin{array}{l}-0.79 * * * \\
(0.24)\end{array}$ & $\begin{array}{l}-1.10^{* * *} \\
(0.30)\end{array}$ \\
\hline Only man's & $\begin{array}{l}-0.36 \\
(0.42)\end{array}$ & $\begin{array}{l}-0.93^{* *} \\
(0.45)\end{array}$ & $\begin{array}{l}-0.34 \\
(0.22)\end{array}$ & $\begin{array}{l}-0.97 * * * \\
(0.25)\end{array}$ & $\begin{array}{l}-1.47 * * * \\
(0.32))\end{array}$ \\
\hline One shared & $\begin{array}{l}0.85^{* * * *} \\
(0.16)\end{array}$ & $\begin{array}{l}1.20 * * * \\
(0.20)\end{array}$ & $\begin{array}{l}0.91 * * * \\
(0.10)\end{array}$ & $\begin{array}{l}1.43^{* * *} \\
(0.13)\end{array}$ & $\begin{array}{l}1.47 * * * \\
(0.14)\end{array}$ \\
\hline Two + shared & $\begin{array}{l}0.50 * * \\
(0.24)\end{array}$ & $\begin{array}{l}0.71 * * \\
(0.34)\end{array}$ & $\begin{array}{l}0.60 * * * \\
(0.14)\end{array}$ & $\begin{array}{l}0.98^{* * *} \\
(0.18)\end{array}$ & $\begin{array}{l}1.37 * * * \\
(0.22)\end{array}$ \\
\hline \multicolumn{6}{|l|}{ Divorce model } \\
\hline Two & $\begin{array}{l}-0.26 \\
(0.19)\end{array}$ & $\begin{array}{l}0.005 \\
(0.26)\end{array}$ & $\begin{array}{l}-0.30^{* *} \\
(0.15)\end{array}$ & $\begin{array}{l}-0.10 \\
(0.20)\end{array}$ & $\begin{array}{l}-0.12 \\
(0.21)\end{array}$ \\
\hline Three & $\begin{array}{l}-0.39 \\
(0.32)\end{array}$ & $\begin{array}{l}0.21 \\
(0.43)\end{array}$ & $\begin{array}{l}-0.48^{* *} \\
(0.19)\end{array}$ & $\begin{array}{l}-0.15 \\
(0.27)\end{array}$ & $\begin{array}{l}-0.09 \\
(0.30)\end{array}$ \\
\hline Four or more & $\begin{array}{l}-0.36 \\
(0.43)\end{array}$ & $\begin{array}{l}0.50 \\
(0.61)\end{array}$ & $\begin{array}{l}-0.74^{* * *} \\
(0.28)\end{array}$ & $\begin{array}{l}-0.19 \\
(0.40)\end{array}$ & $\begin{array}{l}-0.09 \\
(0.47)\end{array}$ \\
\hline \multicolumn{6}{|l|}{ Stepfamily type } \\
\hline No shared & $\begin{array}{l}0.39 \\
(0.51)\end{array}$ & $\begin{array}{l}-0.94 \\
(0.76)\end{array}$ & $\begin{array}{l}1.32 * * * \\
(0.44)\end{array}$ & $\begin{array}{l}0.92 * \\
(0.48)\end{array}$ & $\begin{array}{l}1.11^{* *} \\
(0.52)\end{array}$ \\
\hline Only woman's & $\begin{array}{l}1.35^{* * * *} \\
(0.45)\end{array}$ & $\begin{array}{l}2.96 * * * \\
(0.85)\end{array}$ & $\begin{array}{l}-0.86^{*} \\
(0.50)\end{array}$ & $\begin{array}{l}-0.62 \\
(0.53)\end{array}$ & $\begin{array}{l}-0.74 \\
(0.58)\end{array}$ \\
\hline Only man's & $\begin{array}{l}0.24 \\
(0.68)\end{array}$ & $\begin{array}{l}0.89 \\
(0.88)\end{array}$ & $\begin{array}{l}-0.13 \\
(0.44)\end{array}$ & $\begin{array}{l}0.18 \\
(0.46)\end{array}$ & $\begin{array}{l}0.17 \\
(0.50)\end{array}$ \\
\hline One shared & $\begin{array}{l}-0.03 \\
(0.47)\end{array}$ & $\begin{array}{l}-0.32 \\
(0.54)\end{array}$ & $\begin{array}{l}1.07 * * * \\
(0.22)\end{array}$ & $\begin{array}{l}0.84 * * * \\
(0.26)\end{array}$ & $\begin{array}{l}0.94 * * * \\
(0.27)\end{array}$ \\
\hline Two + shared & $\begin{array}{l}0.27 \\
(0.51)\end{array}$ & $\begin{array}{l}0.09 \\
(0.54)\end{array}$ & $\begin{array}{l}0.63^{* *} \\
(0.26)\end{array}$ & $\begin{array}{l}0.56^{* *} \\
(0.26)\end{array}$ & $\begin{array}{l}0.39 \\
(0.30)\end{array}$ \\
\hline
\end{tabular}




\begin{tabular}{|c|c|c|c|c|c|}
\hline \multicolumn{6}{|c|}{ Heterogeneity model } \\
\hline \multirow[t]{2}{*}{$\operatorname{sig} 1$} & & $0.78 * * *$ & & $0.79 * * *$ & $0.90 * * *$ \\
\hline & & $(0.08)$ & & $(0.06)$ & $(0.06)$ \\
\hline \multirow[t]{2}{*}{$\operatorname{sig} 2$} & & $0.91 * * *$ & & 0.25 & 0.31 \\
\hline & & $(0.26)$ & & $(0.37)$ & $(0.34)$ \\
\hline \multirow[t]{2}{*}{ rho } & & $-0.73 * * *$ & & -1.00 & -0.82 \\
\hline & & $(0.27)$ & & $(1.41)$ & $(0.96)$ \\
\hline In-Likelihood & -6121.3 & -6097.6 & -12167.9 & 12134.2 & 11263.6 \\
\hline
\end{tabular}

Note:

${ }^{a}$ Model did not converge.

${ }^{\mathrm{b}}$ Model based on smaller sample.

Significance: $*=10 \% ; * *=5 \% ; * * *=1 \%$.

The models also control for duration, respondent's age, partner's age and calendar year both in the fertility and the divorce model.

\begin{tabular}{|c|c|c|c|c|}
\hline & \multicolumn{4}{|c|}{ Austria } \\
\hline & \multicolumn{2}{|c|}{ Men } & \multicolumn{2}{|c|}{ Women } \\
\hline & Without & With & Without & With \\
\hline & \multicolumn{2}{|c|}{ Heterogeneity } & \multicolumn{2}{|c|}{ Heterogeneity } \\
\hline \multirow{2}{*}{\multicolumn{5}{|c|}{$\begin{array}{l}\text { Fertility model } \\
\text { Combined parity }\end{array}$}} \\
\hline & & & & \\
\hline Two & $\begin{array}{l}-1.01 * * * \\
(0.11)\end{array}$ & $\begin{array}{l}-1.20^{* * * *} \\
(0.16)\end{array}$ & $\begin{array}{l}-1.09^{* * * *} \\
(0.05)\end{array}$ & $\begin{array}{l}-1.46^{* * * *} \\
(0.07)\end{array}$ \\
\hline Three & $\begin{array}{l}-0.95^{* * * *} \\
(0.17)\end{array}$ & $\begin{array}{l}-1.30^{* * * *} \\
(0.26)\end{array}$ & $\begin{array}{l}-1.36^{* * * *} \\
(0.09)\end{array}$ & $\begin{array}{l}-2.02^{* * * *} \\
(0.12)\end{array}$ \\
\hline Four or more & $\begin{array}{l}-0.93 * * * \\
(0.28)\end{array}$ & $\begin{array}{l}-1.55^{* * * *} \\
(0.40)\end{array}$ & $\begin{array}{l}-1.21^{* * * *} \\
(0.12)\end{array}$ & $\begin{array}{l}-2.29 * * * \\
(0.16)\end{array}$ \\
\hline \multicolumn{5}{|l|}{ Stepfamily type } \\
\hline No shared & $\begin{array}{l}0.36 \\
(0.38)\end{array}$ & $\begin{array}{l}0.72 * \\
(0.41)\end{array}$ & $\begin{array}{l}0.63 * * * \\
(0.18)\end{array}$ & $\begin{array}{l}1.30 * * * \\
(0.21)\end{array}$ \\
\hline Only woman's & $\begin{array}{l}-0.35 \\
(0.45)\end{array}$ & $\begin{array}{l}-0.74 \\
(0.48)\end{array}$ & $\begin{array}{l}-0.48^{* *} \\
(0.20)\end{array}$ & $\begin{array}{l}-0.90^{* * * *} \\
(0.22)\end{array}$ \\
\hline Only man's & $\begin{array}{l}-0.43 \\
(0.45)\end{array}$ & $\begin{array}{l}-0.56 \\
(0.47)\end{array}$ & $\begin{array}{l}-0.46^{* *} \\
(0.22)\end{array}$ & $\begin{array}{l}-1.14^{* * * *} \\
(0.25)\end{array}$ \\
\hline One shared & $\begin{array}{l}0.87 * * * \\
(0.19)\end{array}$ & $\begin{array}{l}1.07 * * * \\
(0.23)\end{array}$ & $\begin{array}{l}0.41 * * * \\
(0.09)\end{array}$ & $\begin{array}{l}0.68 * * * \\
(0.11)\end{array}$ \\
\hline Two + shared & $\begin{array}{l}-0.25 \\
(0.35)\end{array}$ & $\begin{array}{l}-0.12 \\
(0.38)\end{array}$ & $\begin{array}{l}0.16 \\
(0.15)\end{array}$ & $\begin{array}{l}0.31^{*} \\
(0.18)\end{array}$ \\
\hline
\end{tabular}


Appendix B: (Continued)

\begin{tabular}{|c|c|c|c|c|}
\hline & \multicolumn{4}{|c|}{ Austria } \\
\hline & \multicolumn{2}{|c|}{ Men } & \multicolumn{2}{|c|}{ Women } \\
\hline & Without & With & Without & With \\
\hline & \multicolumn{2}{|c|}{ Heterogeneity } & \multicolumn{2}{|c|}{ Heterogeneity } \\
\hline \multicolumn{5}{|l|}{ Divorce model } \\
\hline \multicolumn{5}{|l|}{ Combined parity } \\
\hline Two & $\begin{array}{l}-0.52 * \\
(0.27)\end{array}$ & $\begin{array}{l}-0.31 \\
(0.38)\end{array}$ & $\begin{array}{l}-0.62^{* * * *} \\
(0.12)\end{array}$ & $\begin{array}{l}-0.36^{* *} \\
(0.17)\end{array}$ \\
\hline Three & $\begin{array}{l}-0.50 \\
(0.60)\end{array}$ & $\begin{array}{l}0.09 \\
(0.81)\end{array}$ & $\begin{array}{l}-0.58 * * * \\
(0.17)\end{array}$ & $\begin{array}{l}-0.15 \\
(0.26)\end{array}$ \\
\hline Four or more & $\begin{array}{l}-2.61 \\
(1.64)\end{array}$ & $\begin{array}{l}-1.73 \\
(1.69)\end{array}$ & $\begin{array}{l}-0.32 \\
(0.23)\end{array}$ & $\begin{array}{l}0.32 \\
(0.37)\end{array}$ \\
\hline \multicolumn{5}{|l|}{ Stepfamily type } \\
\hline No shared & $\begin{array}{l}1.69 * \\
(0.95)\end{array}$ & $\begin{array}{l}1.04 \\
(1.16)\end{array}$ & $\begin{array}{l}1.50 * * * \\
(0.31)\end{array}$ & $\begin{array}{l}1.07 * * * \\
(0.38)\end{array}$ \\
\hline Only woman's & $\begin{array}{l}-0.12 \\
(0.95)\end{array}$ & $\begin{array}{l}0.87 \\
(1.17)\end{array}$ & $\begin{array}{l}-0.73^{* *} \\
(0.35)\end{array}$ & $\begin{array}{l}-0.46 \\
(0.39)\end{array}$ \\
\hline Only man's & $\begin{array}{l}0.82 \\
(0.99)\end{array}$ & $\begin{array}{l}1.15 \\
(1.25)\end{array}$ & $\begin{array}{l}-0.49 \\
(0.35)\end{array}$ & $\begin{array}{l}-0.05 \\
(0.40)\end{array}$ \\
\hline One shared & $\begin{array}{l}1.34 * * * \\
(0.43)\end{array}$ & $\begin{array}{l}1.00 \\
(0.62)\end{array}$ & $\begin{array}{l}0.86^{* * *} \\
(0.16)\end{array}$ & $\begin{array}{l}0.70^{* * *} \\
(0.18)\end{array}$ \\
\hline Two + shared & $\begin{array}{l}0.72 \\
(0.92)\end{array}$ & $\begin{array}{l}0.51 \\
(1.06)\end{array}$ & $\begin{array}{l}0.43^{*} \\
(0.26)\end{array}$ & $\begin{array}{l}0.37 \\
(0.27)\end{array}$ \\
\hline \multicolumn{5}{|c|}{ Heterogeneity model } \\
\hline $\operatorname{sig} 1$ & & $\begin{array}{l}0.52 * * * \\
(0.16)\end{array}$ & & $\begin{array}{l}0.72 * * * \\
(0.06)\end{array}$ \\
\hline $\operatorname{sig} 2$ & & $\begin{array}{l}1.21 * * * \\
(0.37)\end{array}$ & & $\begin{array}{l}0.56^{* * * *} \\
(0.22)\end{array}$ \\
\hline rho & & $\begin{array}{l}-0.97 * * * \\
(0.28)\end{array}$ & & $\begin{array}{l}-0.69^{*} \\
(0.37)\end{array}$ \\
\hline Ln-Likelihood & -3655.3 & -3643.2 & -16325.3 & -16294.2 \\
\hline
\end{tabular}

Note: Significance: $*=10 \% ; * *=5 \% ; * * *=1 \%$.

The models also control for duration, respondent's age, partner's age and calendar year both in the fertility and the divorce model. 


\begin{tabular}{|c|c|c|c|c|}
\hline & \multicolumn{4}{|c|}{ West Germany } \\
\hline & \multicolumn{2}{|c|}{ Men } & \multicolumn{2}{|c|}{ Women } \\
\hline & Without & With & Without & With \\
\hline & \multicolumn{2}{|c|}{ Heterogeneity } & \multicolumn{2}{|c|}{ Heterogeneity } \\
\hline \multirow{2}{*}{\multicolumn{5}{|c|}{$\begin{array}{l}\text { Fertility model } \\
\text { Combined parity }\end{array}$}} \\
\hline & & & & \\
\hline Two & $\begin{array}{l}-1.22^{* * *} \\
(0.18)\end{array}$ & $\begin{array}{l}-1.30^{* * *} \\
(0.35)\end{array}$ & $\begin{array}{l}-1.17^{* * * *} \\
(0.11)\end{array}$ & $\begin{array}{l}-1.50^{* * * *} \\
(0.17)\end{array}$ \\
\hline Three & $\begin{array}{l}-2.23^{* * * *} \\
(0.56)\end{array}$ & $\begin{array}{l}-2.39 * * * \\
(0.73)\end{array}$ & $\begin{array}{l}-1.17 * * * \\
(0.21)\end{array}$ & $\begin{array}{l}-1.77^{* * * *} \\
(0.32)\end{array}$ \\
\hline Four or more & $\begin{array}{l}-2.35 \\
(2.73)\end{array}$ & $\begin{array}{l}-2.55 \\
(3.24)\end{array}$ & $\begin{array}{l}-2.41 * * * \\
(0.70)\end{array}$ & $\begin{array}{l}-3.37 * * * \\
(0.79)\end{array}$ \\
\hline \multicolumn{5}{|l|}{ Stepfamily type } \\
\hline No shared & $\begin{array}{l}1.10^{*} \\
(0.66)\end{array}$ & $\begin{array}{l}1.28 * \\
(0.72)\end{array}$ & $\begin{array}{l}0.83^{*} \\
(0.47)\end{array}$ & $\begin{array}{l}1.34 * * * \\
(0.51)\end{array}$ \\
\hline Only woman’s & $\begin{array}{l}-0.52 \\
(0.68)\end{array}$ & $\begin{array}{l}-0.57 \\
(0.68)\end{array}$ & $\begin{array}{l}-0.66 \\
(0.49)\end{array}$ & $\begin{array}{l}-0.96^{*} \\
(0.53)\end{array}$ \\
\hline Only man's & $\begin{array}{l}-1.18 \\
(0.90)\end{array}$ & $\begin{array}{l}-1.36 \\
(0.93)\end{array}$ & $\begin{array}{l}-0.65 \\
(0.49)\end{array}$ & $\begin{array}{l}-1.05^{* *} \\
(0.53)\end{array}$ \\
\hline One shared & $\begin{array}{l}0.48 \\
(0.50)\end{array}$ & $\begin{array}{l}0.52 \\
(0.57)\end{array}$ & $\begin{array}{l}0.70 * * * \\
(0.25)\end{array}$ & $\begin{array}{l}0.93 * * * \\
(0.27)\end{array}$ \\
\hline Two + shared & $\begin{array}{l}1.79 * * \\
(0.78)\end{array}$ & $\begin{array}{l}1.86^{*} \\
(0.96)\end{array}$ & $\begin{array}{l}0.62 \\
(0.50)\end{array}$ & $\begin{array}{l}0.79 \\
(0.59)\end{array}$ \\
\hline \multicolumn{5}{|l|}{ Divorce model } \\
\hline Two & $\begin{array}{l}-0.66 \\
(0.62)\end{array}$ & $\begin{array}{l}-1.51 \\
(1.17)\end{array}$ & $\begin{array}{l}-0.34 \\
(0.23)\end{array}$ & $\begin{array}{l}-0.09 \\
(0.39)\end{array}$ \\
\hline Three & $\begin{array}{l}-0.41 \\
(0.73)\end{array}$ & $\begin{array}{l}-1.83 \\
(2.31)\end{array}$ & $\begin{array}{l}-0.78 \\
(0.55)\end{array}$ & $\begin{array}{l}-0.38 \\
(0.75)\end{array}$ \\
\hline Four or more & $\begin{array}{l}1.18 \\
(1.57)\end{array}$ & $\begin{array}{l}0.86 \\
(4.66)\end{array}$ & $\begin{array}{l}-0.25 \\
(0.63)\end{array}$ & $\begin{array}{l}0.25 \\
(0.69)\end{array}$ \\
\hline \multicolumn{5}{|l|}{ Stepfamily type } \\
\hline No shared & $\begin{array}{l}2.57 * * \\
(1.20)\end{array}$ & $\begin{array}{l}2.29 \\
(3.34)\end{array}$ & $\begin{array}{l}0.10 \\
(0.97)\end{array}$ & $\begin{array}{l}0.81 \\
(1.12)\end{array}$ \\
\hline Only woman's & $\begin{array}{l}-0.16 \\
(1.15)\end{array}$ & $\begin{array}{l}1.34 \\
(3.87)\end{array}$ & $\begin{array}{l}0.08 \\
(0.98)\end{array}$ & $\begin{array}{l}0.16 \\
(1.14)\end{array}$ \\
\hline Only man's & $\begin{array}{l}-0.36 \\
(1.06)\end{array}$ & $\begin{array}{l}0.95 \\
(3.14)\end{array}$ & $\begin{array}{l}-0.10 \\
(1.01)\end{array}$ & $\begin{array}{l}0.02 \\
(1.13)\end{array}$ \\
\hline One shared & $\begin{array}{l}0.21 \\
(1.38)\end{array}$ & $\begin{array}{l}0.29 \\
(2.09)\end{array}$ & $\begin{array}{l}0.88^{* *} \\
(0.42)\end{array}$ & $\begin{array}{l}0.69 \\
(0.48)\end{array}$ \\
\hline
\end{tabular}


Appendix B: (Continued)

\begin{tabular}{|c|c|c|c|c|}
\hline & \multicolumn{4}{|c|}{ West Germany } \\
\hline & \multicolumn{2}{|c|}{ Men } & \multicolumn{2}{|c|}{ Women } \\
\hline & Without & With & Without & With \\
\hline & \multicolumn{2}{|c|}{ Heterogeneity } & \multicolumn{2}{|c|}{ Heterogeneity } \\
\hline Two + shared & $\begin{array}{l}0.62 \\
(2.84)\end{array}$ & $\begin{array}{l}-0.88 \\
(6.21)\end{array}$ & $\begin{array}{l}0.77 \\
(0.90)\end{array}$ & $\begin{array}{l}0.66 \\
(1.00)\end{array}$ \\
\hline Heterogeneity mo & & & & \\
\hline $\operatorname{sig} 1$ & & $\begin{array}{l}0.32 \\
(0.54)\end{array}$ & & $\begin{array}{l}0.69 * * * \\
(0.14)\end{array}$ \\
\hline $\operatorname{sig} 2$ & & $\begin{array}{l}2.77 * * \\
(1.34)\end{array}$ & & $\begin{array}{l}0.81 * * \\
(0.36)\end{array}$ \\
\hline rho & & $\begin{array}{l}-0.07 \\
(0.89)\end{array}$ & & $\begin{array}{l}-0.54 \\
(0.54)\end{array}$ \\
\hline ln-Likelihood & -1567.5 & -1558.9 & -4198.2 & -4194.5 \\
\hline
\end{tabular}

Note: Significance: $*=10 \% ; * *=5 \% ; * * *=1 \%$

The models also control for duration, respondent's age, partner's age and calendar year both in the fertility and the divorce model.

\section{References}

Andersson, G. and Philipov, D., 2002. 'Life-table representations of family dynamics in Sweden, Hungary, and 14 other FFS countries: A project of descriptions of demographic behavior', Demographic Research 7: 68-144, Available online at http://www.demographicresearch.org/volumes/vol7/4.

Baizán, P., Aassve A. and Billari F. C., 2003. 'Cohabitation, marriage, first birth: The interrelationship of family formation events in Spain', European Journal of Population 19: $147-169$.

Booth, A. and Edwards, J. N., 1992. 'Starting over: Why remarriages are more unstable', Journal of Family Issues 13: 179-94.

Bosveld, W., 1996. The Ageing of Fertility in Europe: A Comparative Demographic-Analytic study. Doctoral thesis, Netherlands Graduate School of Research in Demography. (Thesis Publishers, Amsterdam).

Buber, I. and Prskawetz, A., 2000. 'Fertility in second unions in Austria: Findings from the Austrian FFS', Demographic Research 3/2 (http://www.demographic-research.org/ Volumes/Vol3/2).

Bulatao, R. A., 1981. 'Values and disvalues of children in successive childbearing decisions', Demography 18: 1-25.

Fawcett, J. T., 1983. 'Perceptions of the value of children: Satisfactions and costs', in: R. A. Bulatao and R. D. Lee (eds.), Determinants of Fertility in Developing Countries Vol. 2: Supply and Demand for Children. Academic Press, New York.

Findl, P., 1991. 'Austria', in: J. L. Rallu and A. Blum (eds.), European Population, Vol. 1. Country Analysis. John Libbey, London 225-236. 
Ganong, L. H. and Coleman M., 1988. 'Do mutual children cement bonds in stepfamilies?', Journal of Marriage and the Family 50: 687-98.

Griffith, J. D., Koo, H. P. and Suchindran, C. M., 1985. 'Childbearing and family in remarriage', Demography 22: 73-88.

Höhn, C., 1991. 'Germany', in J. L. Rallu and A. Blum (eds.), European Population, Vol. 1. Country Analysis. John Libbey, London 83-111.

Kiernan, K., 1999. 'Childbearing outside marriage in Western Europe', Population Trends 98: $11-20$.

Lillard, L. A., 1993. 'Simultaneous equations for hazards: Marriage duration and fertility timing', Journal of Econometrics 56: 189-217.

Lillard, L.A., Brien, M.J., and Waite, L.J., 1995. 'Premarital co-habitation and subsequent marital dissolution - A matter of self selection', Demography 32: 437-457.

Lillard, L. A. and Panis, C. W. A., 2000. aML Multilevel Multiprocess Statistical Software, Release 1.0. EconWare, CA, Los Angeles.

Lillard, L. A. and Waite, L. J., 1993. 'A joint model of marital childbearing and marital disruption', Demography 30: 653-681.

Martin, T. C. and Bumpass L. L., 1989. 'Recent trends in marital disruption', Demography 26: $37-51$.

Nikander, T., 1998. Fertility and Family Surveys in Countries of the ECE Region, Standard Country Report, Finland, United Nations, New York.

Olah, L. Sz., 2001. Gendering Family Dynamics: The Case of Sweden and Hungary, Doctoral Thesis (Stockholm University, Demography Unit, Stockholm).

Orloff, A., 1996. 'Gender in the welfare state', Annual Review of Sociology 22: 51-78.

Prinz, C., 1995. Cohabiting, Married or Single: Portraying, Analyzing, and Modeling New Living Arrangements in the Changing Societies of Europe. Avebury, Aldershot, England.

Prinz, C., 1998. Fertility and Family Surveys in Countries of the ECE Region, Standard Country Report, Austria. United Nations, New York.

Rönsen, M. and Sundström, M., 1997. 'Women's return to work after first birth in the Nordic countries - full time or part time?', Stockholm Research Reports in Demography 112, Stockholm University, Demography Unit.

Schoen, R., Urton, W., Woodrow, K. and Baj, J., 1985. 'Marriage and divorce in $20^{\text {th }}$ century American cohorts', Demography 22: 101-114.

Stewart, S. D., 2002. 'The effect of stepchildren on childbearing intentions and births', Demography 39: 181-197.

Thomson, E., 1997. 'Her, his and their children: Influences on couple childbearing decisions', NSFH Working Paper \# 76, Center for Demography and Ecology, University of Wisconsin-Madison, Madison WI.

Thomson, E., Hoem, J. M., Vikat, A., Prskawetz, A., Buber, I., Toulemon, L., Henz, U., Godecker, A. L. and Kantorova, V., 2002. 'Childbearing in stepfamilies: how parity matters', in: E. Klijzing and M. Corijn (eds.), Fertility and Partnership in Europe: Findings and Lessons from Comparative Research, Vol. II. United Nations: Geneva/New York 87-99.

Toulemon, L. and de Guibert-Lantoine, C., 1998. Fertility and Family Surveys in Countries of the ECE Region, Standard Country Report, France, United Nations, New York.

Upchurch, D.M., Lillard, L. A. and Panis, C. W. A., 2002. 'Nonmarital childbearing: Influences of education, marriage and fertility', Demography 39: 311-329.

Vikat, A., Thomson, E. and Hoem, J. M., 1999. 'Stepfamily fertility in contemporary Sweden: The impact of childbearing before the current union', Population Studies 53: 211-25.

Vikat, A., Thomson, E. and Prskawetz, A., 2004. 'Childrearing responsibility and stepfamily fertility in Finland and Austria', European Journal of Population 20: 1-21. 
Copyright of European Journal of Population is the property of Springer Science \& Business Media B.V. and its content may not be copied or emailed to multiple sites or posted to a listserv without the copyright holder's express written permission. However, users may print, download, or email articles for individual use. 